\title{
SEASONAL FLUCTUATIONS OF BIOCHEMICAL PARAMETERS IN POSTPARTUM GOATS OF LOCAL CROSS BREEDS REARED IN THE REGION OF TIARET, ALGERIA
}

\author{
Berrani Abdelkader $^{1 *}$, Meliani Samia ${ }^{1}$, BourabehAkila ${ }^{2}$, Berrouaguia Karim ${ }^{1}$ \\ ${ }^{1 *}$ Nature and Life Sciences Faculty, University of Tiaret (14000), Algeria; \\ ${ }^{2}$ Veterinary Sciences Institute, University of Tiaret (14000), Algeria; \\ "Corresponding Author Berrani Abdelkader, e-mail : kadibiovet@gmail.com;
}

Received April 2021; Accepted May 2021; Published June 2021;

DOI: $\underline{\text { https://doi.org/10.31407/ijees11.328 }}$

\begin{abstract}
The aim of this study was to assess the variations of certain biochemical parameters in postpartum goats in two seasons (spring and winter). A total of fifty goats of local cross breeds in their twentieth days after parturition were used in the experiment from 2019 to 2020. Animals were reared in Tiaret region in the north-west of Algeria $\left(35^{\circ} 22^{\prime}\right.$ $\mathrm{N}, 1^{\circ} 19^{\prime} \mathrm{E}$ ) under semi-arid environment. Two blood samples were taken in heparin vacuum tubes, 25 samples in each season winter and spring, the blood was centrifuged at 3000 round for 10 minutes, The assay of the biochemical substrates was carried out with a "Beckman coutter" biochemical analyzer. Our results show that all the mean values recorded during this study were within the range of standards cited in the literature and the season had a significant influence $(\mathrm{p}<0.05)$ on creatinine and calcium with high values in winter and decreases in spring, while the values of triglycerides, total protein and globulin were higher in winter and lower in spring without any significant difference, unlike the average values of urea, albumin, and phosphorus that increase in spring and decrease in winter. The results of this study could serve as reference values for local Algerian goats in postpartum and goats from other regions or countries with similar climatic and physiological conditions.
\end{abstract}

Keywords: goats, season, winter, spring, postpartum, biochemical parameters. 